\title{
Importance Performance Analysis and Servqual Analysis for Measuring Students Satisfaction Levels Towards Facilities in the Classroom
}

\author{
Zuhut Ramdani $^{1 *}$ and Wiwit Pura Nurmayanti ${ }^{2}$
}

\author{
${ }^{12}$ Universitas Hamzanwadi, Selong, Indonesia. \\ ${ }^{1}$ Department in Early Childhood Education Program, Universitas Hamzanwadi, Selong, Indonesia. \\ ${ }^{2}$ Department of Statistics, Faculty of Mathematics and Natural Sciences, Universitas Hamzanwadi, Selong, Indonesia. \\ *Corresponding author. Email: ramdanizuhud@gmail.com
}

\begin{abstract}
If a university is to be qualified, it must provide the best for its students, one of which is in terms of facilities. What is meant by facilities here are all the needs needed by students to facilitate, expedite and support in learning activities in classroom. Students will feel satisfied with the facilities provided if the facilities provided can support their learning system. Hamzanwadi University is one of the private universities that tries to provide the best for its students, one of which is in terms of facilities. However, the facilities provided on this campus are often complained of by students, therefore this research aims to study the level of appropriateness between perceptions and student expectations for the classroom. From the results of the analysis using Importance Performance Analysis and servqual analysis we found it that the service from the Hamzanwadi University campus to the classroom facilities could meet $50.30 \%$ of student expectations and still needed to be improved and increased by $49.70 \%$ in other services.
\end{abstract}

Keywords: Facilities, Classrooms, Important Performance Analysis, Servqual Analysis

\section{INTRODUCTION}

The university of to be familiar qualified and advance, it must provide the best for its students, both in terms of facilities and teaching techniques (Lynch, 2003), (Riley, Kokkarinen, \& Pitt, 2010). Facilities that support student learning activities are very important, because students are easier to understand the subjects studied (Amaratunga \& Baldry, 2000), (Napitupulu et al., 2018). What is meant by facilities here are all the needs needed by students to facilitate, facilitate and support learning activities in the classroom. Students will feel satisfied with the facilities provided if the facilities provided can support their learning system (Yunus, Ishak, \& Razak, 2010), (Napitupulu et al., 2018).

Students' perceptions about the classrooms they use are very important because this can be one benchmark for the faculty themselves, where the faculty can see if the performance is good (Sandilos, Rimm-Kaufman, \& Cohen, 2017), (Hassan, Alias, Saleh, \& Awang, 2017). Many researches related to facilities and student satisfaction have been done, among others by Boky Yonas (2016), which examines the level of student satisfaction with academic services at Jaffray Theological College. From the results of his analysis, Boky Yonas concluded that students were quite satisfied with the academic services provided by the campus in terms of reliability, responsiveness, assurance and empathy, but students were not satisfied with educational facilities, especially classrooms (Boky, 2016). Boky Yonas in his research used descriptive analysis to see the level of student satisfaction, but it is better in the study not only to use descriptive analysis but also to be followed by a more in-depth analysis. Basically descriptive analysis only provides a general description of the characteristics of the data to be analyzed (Thorne, 2016), (Kechris \& Marks, 2016), so researchers could not draw conclusions directly to answer the objectives of the research. Other research related to facilities and satisfaction was carried out by Sukandi Pipin (2010) with a case study of the Faculty of Business and Management students at Widyatama University, the aim of the research was to look at the relationship between campus facilities and student satisfaction. The results of his research show that there is a positive relationship between campus facilities and student satisfaction, but the value of the relationship is still very small at only $4 \%$. The sampling technique used by Sukandi Pipin is a simple random sampling and is carried out in only one faculty out of five faculties at Widyatama University (Sukandi, 2010). In a research data must be representative so it will give the right results (Taherdoost, 2016), but in Sukandi Pipin research the data analyzed are not yet representative 
because the application of the sampling technique is not appropriate. As a result, the conclusions drawn will be wrong. So that further research is needed to improve and complete previous studies conducted by Boky Yonas and Sukandi Pipin.

Hamzanwadi University is one of the best private universities in the province of West Nusa Tenggara (NTB), on this campus there are four faculties namely the Teaching and Education Faculty (FKIP), the Faculty of Engineering, Health and Mathematics and Natural Sciences (Universitas Hamzanwadi, 2019). The service provided to students is one of the important points to be considered by the campus which is familiar cultured by santri, including the facilities in the classroom. The facilities provided in each classroom are blackboards and LCD, and chairs that sometimes exceed student capacity. However, students on this campus often complain about their classrooms, because besides improving and completing previous researchers are also interested in examining the level of student satisfaction with classroom facilities at Hamzanwadi University. The purpose of this study was to determine the level of appropriateness between perceptions and student expectations for classroom facilities.

\section{METHOD}

Data

The data used in this study are primary data. Primary data were taken from questionnaires given to students who were selected as samples.

The observed variables in this research are Complete equipment (size of the whiteboard, enough seats are available, LCDs are available in every classroom, Markers and Erasers are always available, air conditioning is available, every window is provided curtains, trash bins available, cleanliness (floors in a clean room, clean tables and chairs, Clean white board, clean curtains, bright wall)

\section{Method}

Data analysis methods used in this study are Importance Performance Analysis and Servqual Analysis. The stages of analysis in this research are:
1. Do descriptive analysis data to observe the general overview;

2. Conduct an analysis using the importance of Performance Analysis to see students' expectations of the classroom facilities provided by the Hamzanwadi University;

3. Conduct analysis using Servqual Analysis to measure the gap between expectations and perceptions in each indicator in the service dimensions of the Hamzanwadi University;

4. Conclusions.

\section{RESULTS AND DISCUSSION}

\section{Descriptive Statistics}

Based on the results of descriptive analysis obtained information:

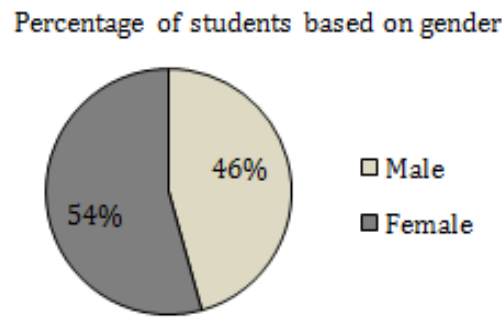

Figure 1 Percentage of students based on gender

Figure 1 showed that students participating in this study consisted $45.65 \%$ of men and $54.35 \%$ of women.

\section{Importance Performance Analysis}

From 333 questionnaires got information that the total value given by students on perception is 13046.80 and expectations of 25939.96 thus the level of correspondence between students' perceptions and expectations of class facilities is:

$$
K_{i}=\frac{13046.80}{25939.96} \times 100 \%=50.30 \%
$$

The above conditions show that the students' expectation of the classroom facilities provided by Hamzanwadi University can only meet $50.30 \%$ and still needs to be improved and increased $49.70 \%$ in other facilities. When seen, the suitability of each indicator in the dimensions shows the results in Table 1:

Table 1. Stress Value for each Attribute in Cosmetic Brands

\begin{tabular}{|c|c|l|c|c|c|}
\hline Variable & Item & \multicolumn{1}{|c|}{ Indicator } & perception & expectation & suitability level \\
\hline Completeness & $\mathrm{p} 1$ & The size of the white board is quite large & 630.00 & 1572.00 & 40.08 \\
\hline & $\mathrm{p} 2$ & Chairs are enough & 1288.70 & 1617.36 & 79.68 \\
\hline & $\mathrm{p} 3$ & LCD is available in every classroom & 718.18 & 1622.74 & 44.26 \\
\hline & $\mathrm{p} 4$ & Markers and erasers are always available & 1357.50 & 1660.43 & 81.76 \\
\hline & $\mathrm{p} 5$ & Availability of air conditioning (AC) & 580.00 & 1621.25 & 35.77 \\
\hline
\end{tabular}




\begin{tabular}{|c|c|l|c|c|c|}
\hline & $\mathrm{p} 6$ & there are curtains in each class window & 599.45 & 1619.36 & 37.02 \\
\hline & $\mathrm{p} 7$ & trash bin be available & 619.51 & 1624.63 & 38.13 \\
\hline & $\mathrm{p} 8$ & Wall clock available & 477.40 & 1628.70 & 29.31 \\
\hline Cleanliness & $\mathrm{p} 9$ & The floor in the classroom is clean & 1144.20 & 1620.50 & 70.61 \\
\hline & $\mathrm{p} 10$ & tables and chairs is Clean & 762.49 & 1618.28 & 47.12 \\
\hline & $\mathrm{p} 11$ & white board is Clean & 1017.59 & 1621.90 & 62.74 \\
\hline & $\mathrm{p} 12$ & Curtains Clean & 527.09 & 1622.90 & 32.48 \\
\hline & $\mathrm{p} 13$ & No graffiti on the wall & 1148.57 & 1622.00 & 70.81 \\
\hline \multirow{2}{*}{ Aesthetics } & $\mathrm{p} 14$ & the chairs are neatly & 835.92 & 1622.98 & 51.51 \\
\hline & $\mathrm{p} 15$ & Bright wall colours & 523.57 & 1622.59 & 50.76 \\
\hline
\end{tabular}

Table 1 provides information related to the level of conformity between perceptions and expectations of each indicator / statement item in the form of a large percentage of a solution of student expectations by Hamzanwadi University. Of all the indicators studied, there are several indicators that have met student expectations above the $50 \%$ level, namely three indicators on completeness variables (p2, p4, and p9), two indicators on cleanliness variables (p11 and p13), and two indicators on aesthetic variables (p14 and p15). Indicators that should get more attention by the campus management are six indicators on completeness variables (p1, p3, p5, p6, p7, and p8), two indicators on cleanliness variables (p10 and p12), and one indicator on aesthetic variables (p16). These indicators are related to The size of the white board is quite large (p1), LCD (p3), air conditioner (p5), there are curtains in each class window (p6), trash bin (p7), wall clock (p8), tables and chairs is Clean (p10), curtains (p12), and wall decoration (p16).

\section{Servqual Analysis}

To measure the gap between expectations and perceptions, it is necessary to calculate the mean of each indicator in the service dimensions of the Hamzanwadi University campus. The following result the gap between students' expectations and perceptions:

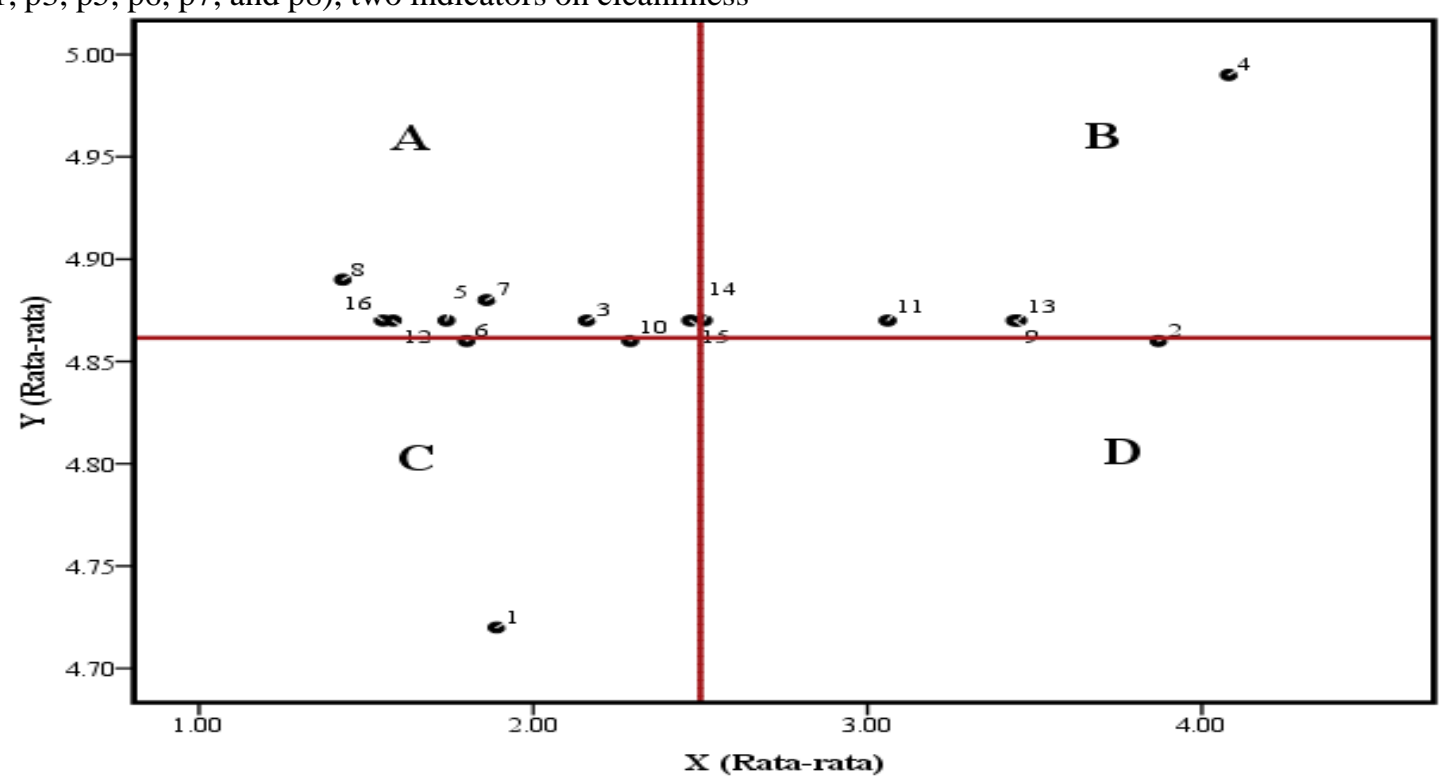

Figure 2 Customer Window

The information got from Figure 2 is an indicator or attribute that must be a top priority for improvement and improvement in quadrant A, namely (Sever, 2015),
(Khorshidi, Nikfalazar, \& Gunawan, 2016): LCD is available in every classroom (p3), Availability of air conditioning (p5), trash bin be available (p7), Wall clock 
available (p8), Curtains Clean (p12), Bright wall colours (p15), and decoration in the wall available (p16).

For indicators or attributes the Campus management must maintain that in quadrant B namely (Sever, 2015): Chairs are enough (p2), The floor in the classroom is clean (p), white board is Clean (p11), No graffiti on the wall (p13), and the chairs are neatly (p14).

Indicators or attributes that are felt to be less important and unsatisfactory by students so that students behave indifferent in the C quadrant, namely (Dabestani, Shahin, \& Saljoughian, 2017): the size of the white board is quite large (p1), there are curtains in each class window (p6), and trash bin be available (p7).

Indicators or attributes students feels that are not so important but students very satisfied there is in quadrant $\mathrm{D}$ that is the indicator of available seats enough (p2).

\section{CONCLUSIONS}

The service from Hamzanwadi University for classroom facilities has met $50.30 \%$ of student expectations and needs to improve and increase by $49.70 \%$ in other services.

\section{ACKNOWLEDGMENTS}

This study was supported by a grant from the P3MP Hamzanwadi University. We also would like to thank Suci Murni and Wiyatna for fruitful discussions as well as their support and encouragement.

\section{REFERENCES}

[1] Amaratunga, D., \& Baldry, D. (2000). Assessment of facilities management performance in higher education properties. Facilities, 18(7/8), 293-301.

[2] Boky, Y. (2016). Analisis Tingkat Kepuasan Mahasiswa Terhadap Pelayanan Akademik Sekolah Tinggi Theologia Jaffray Makassar. Jurnal Jaffray, 14(2), 269-290.

[3] Dabestani, R., Shahin, A., \& Saljoughian, M. (2017). Evaluation and prioritization of service quality dimensions based on gap analysis with analytic network process. International Journal of Quality \& Reliability Management, 34(4), 530-548.

[4] Hassan, B., Alias, M., Saleh, K. M., \& Awang, H. (2017). Students' perceptions of their teachers' performance in teaching engineering drawing in Nigerian tertiary institutions. Traektoriâ Nauki= Path of Science, 3(10).

[5] Kechris, A. S., \& Marks, A. S. (2016). Descriptive graph combinatorics. Preprint, 4

[6] Khorshidi, H. A., Nikfalazar, S., \& Gunawan, I. (2016). Statistical process control application on service quality using SERVQUAL and QFD with a case study in trains' services. The TQM Journal, 28(2), 195-215.

[7] Lynch, C. A. (2003). Institutional repositories: essential infrastructure for scholarship in the digital age. Portal: Libraries and the Academy, 3(2), 327336.

[8] Napitupulu, D., Rahim, R., Abdullah, D., Setiawan, M. I., Abdillah, L. A., Ahmar, A. S., ... Pranolo, A. (2018). Analysis of student satisfaction toward quality of service facility. Journal of Physics: Conference Series, 954(1), 12019. IOP Publishing.

[9] Riley, M., Kokkarinen, N., \& Pitt, M. (2010). Assessing post occupancy evaluation in higher education facilities. Journal of Facilities Management, 8(3), 202-213.

[10] Sandilos, L. E., Rimm-Kaufman, S. E., \& Cohen, J. J. (2017). Warmth and demand: The relation between students' perceptions of the classroom environment and achievement growth. Child Development, 88(4), 1321-1337.

[11] Sever, I. (2015). Importance-performance analysis: A valid management tool? Tourism Management, 48, 43-53.

[12] Sukandi, P. (2010). Hubungan Antara Fasilitas Kampus Terhadap Kepuasan Mahasiswa Dalam Menghadapi Daya Saing Jasa Pendidikan (Studi Kasus : Mahasiswa Fakultas Bisnis dan Manajemen Universitas Widyatama). The 4th PPM National Conference on Management Research Jakarta, 25 November 2010, 9(November).

[13] Taherdoost, H. (2016). Sampling methods in research methodology; how to choose a sampling technique for research. How to Choose a Sampling Technique for Research (April 10, 2016).

[14] Thorne, S. (2016). Interpretive description: Qualitative research for applied practice. Routledge.

[15] Universitas Hamzanwadi. (2019) https://hamzanwadi.ac.id/. Retrieved from https://hamzanwadi.ac.id/

[16] Yunus, N. K. Y., Ishak, S., \& Razak, A. Z. A. A. (2010). Motivation, empowerment, service quality and polytechnic students' level of satisfaction in Malaysia. International Journal of Business and Social Science, 1(1). 